\title{
FEDERAL PROTECTION OF NEGRO VOTING RIGHTS
}

\author{
Burke Marshall*
}

For ninety-four years our Constitution has forbidden the states and their officials to deny any of our citizens the right to vote on account of their race. ${ }^{1}$ The broader right to vote freely in national elections is a privilege of United States citizenship that federal law has long protected from arbitrary infringement-state or private. ${ }^{2}$

Despite these long-standing guarantees, the United States Commission on Civil Rights has found that racial denials of the right to vote occur in sections of eight states. ${ }^{3}$ In five of those states Negroes constitute more than a quarter of the adult population, but very few of these Negroes are registered to vote. For example, in Mississippi only five per cent are registered; in Alabama only fourteen per cent are registered; in South Carolina, sixteen per cent are registered; in Georgia, twenty-six per cent are registered; and in Louisiana, twenty-nine per cent are registered. Registration among adult whites invariably exceeds fifty per cent. In eleven counties where Negroes are in the majority none is registered. ${ }^{4}$ In ninety-seven counties fewer than five per cent of the adult Negroes are on the rolls.5 Indeed, in most counties with sizable Negro populations the Negro voter totals are significantly below the statewide percentage of eligible Negroes registered and neither figure approaches the white voter percentage. ${ }^{6}$

In our experience Negro non-voting results almost exclusively from racial discrimination by state officials and fear among Negroes engendered by the attitudes and actions of white persons-including some office-holders. ${ }^{7}$

- B.A. 1944, LL.B. 195r, Yale University. Assistant Attorney General, Civil Rights Division, United States Department of Justice.

This article, like the work of the Division, incorporates and reflects the work of a number of extraordinarily hard-working and able lawyers in the Division. Among them, the accredited author wishes particularly to thank David L. Norman, in connection with the preparation of this manuscript.

I Ratifications of the fourteenth and fifteenth amendments were completed in 1868 and 1870 , respectively. The more explicit fifteenth amendment proscribes only racial distinctions. United States v. Reese, 92 U.S. 214 ( 1876 ); the fourteenth amendment enjoins all wholly arbitrary voting denials, including racial ones. Baker v. Carr, 369 U.S. 186 (1962); Nixon v. Herndon, 273 U.S. 536 (1927). This paper is confined to the problems of racial disfranchisement because Negroes comprise the only minority group whose voting rights are substantially abridged. UNITED STATES Commission on Civil Rigrits, REPORT I8 (196I) [hereinafter cited as C.R.C. REPORT].

${ }^{2}$ Ex parte Yarbrough, 110 U.S. 65I (1884); Twining v. New Jersey, 2 II U.S. 78, 97 (I908) (dictum); I8 U.S.C. $\$ 241$ (1958).

${ }^{3}$ C.R.C. Report 22 (I96r): Alabama, Florida, Georgia, Louisiana, Mississippi, North Carolina, South Carolina, and Tennessee.

'Lowndes and Wilcox counties, Alabama; Webster County, Georgia; Issaquena, Jefferson, Noxubee, and Tallahatchie counties, Mississippi; and East Carroll, Madison, Tensas, and West Feliciana parishes, Louisiana.

"Ten counties in Alabama; three counties in Florida; sixteen counties in Georgia; forty-seven counties in Mississippi; seven counties in South Carolina; and fourteen parishes in Louisiana.

${ }^{\circ}$ C.R.C. REPORT 52-53 (1959).

${ }^{7}$ Discrimination by registration officials has secondary effects. We were once puzzled by counties in 
This paper explores our problems: the techniques of discrimination and intimidation, and the present efforts of the United States Department of Justice to secure to all the right to vote without distinction of race.

\section{Federal Law}

- After more than eighty years of civil rights desuetude, Congress adopted a voting statute in 1957-the Civil Rights Act of 1957. Together, the act's four principal sections authorize the Attorney General to institute civil suits in the federal district courts (regardless of whether the persons aggrieved have exhausted other remedies) to prevent and redress racial and other arbitrary interferences with the right to vote. ${ }^{8}$

which, although fear was not a factor, few Negroes applied to register. We bnow now that the bulk of a Negro community considers attempting to register to be an idle gesture after a few of their teachers and ministers have been rejected as unqualified. For instance, in Bullock County, Alabama, only five Negroes were registered when the Justice Department brought suit in 196r. During 1960 only one Negro, a minister, had applied. He was rejected twice. Today he and more than 700 others are on the rolls.

${ }^{8} 71$ Stat. 637 (1957), 42 U.S.C. \$ 197 (1958):

(a) All citizens of the United States who are otherwise qualified by law to vote at any election by the people in any State, Territory, district, county, city, parish, township, school district, municipality, or other territorial subdivision, shall be entitled and allowed to vote at all such elections, without distinction of race, color, or previous condition of servitude; any constitution, law, custom, usage, or regulation of any State or Territory, or by or under its authority, to the contrary notwithstanding.

(b) No person, whether acting under color of law or otherwise, shall intimidate, threaten, cocrec, or attempt to intimidate, threaten, or coerce any other person for the purpose of interfering with the right of such other person to vote or to vote as he may choose, or of causing such other person to vote for, or not to vote for, any candidate for the office of President, Vice President, presidential elector, Member of the Senate, or Member of the House of Representatives, Delegates or Commissioners from the Territories or possessions, at any general, special, or primary election held solely or in part for the purpose of selecting or electing any such candidate.

(c) Whenever any person has engaged or there are reasonable grounds to believe that any person is about to engage in any act or practice which would deprive any other person of any right or privilege secured by subsection (a) or (b), the Attorney General may institute for the United States, or in the name of the United States, a civil action or other proper proceeding for preventive relief, including an application for a permanent or temporary injunction, restraining order, or other order. In any proceeding hereunder the United States shall be liable for costs the same as a private person.

(d) The district courts of the United States shall have jurisdiction of proceedings instituted pursuant to this section and shall exercise the same without regard to whether the party aggrieved shall have exhausted any administrative or other remedies that may be provided by law.

Read narrowly, the sections seem not to reach all deprivations of voting rights. For instance, under subsection (b) may I harass a registration organizer whose right to vote in federal elections is far from my mind because he is domiciled in a distant state? No, because of the effects of my actions on the local Negro community. See United States v. Wood, 295 F.2d 772 (5th Cir. 1961), cert. denied, 369 U.S. 850 (1962). May one intimidate me with impunity because his only purpose is to deter my participation in local elections? Definitely not, if my registration is interfered with because, in the absence of a split registration system, I am signing up to vote federally as well as locally, and the actor's purposes should be inferred from the effects he produces, not his secret intentions. See United States v. Beatty, 288 F.2d 653 (6th Cir. I96I); United States v. Ellis, 43 F. Supp. 321, 324 (W.D.S.C. r942). Subsection (b) should also protect a registrant who is threatened as he approaches the polling place in a non-federal clection, because again, whatever the actor's personal motive, the deterrent effect of that threat will extend to federal voting. See I Thomas Emerson \& David Haber, Polimcal and Civil Rights in t7ie UNitho States 68 (2d ed. I958).

Conceivably, a private person could deny another the right to vote for racial reasons by some means other than threats, intimidation, or coercion. Any such conduct could be attacked under subsection (a) if it occurred in a federal election. Even in a non-federal election it could probably be reached by a conspiracy theory because peaceable deprivations of voting rights are virtually impossible without some 
In Ig60 Congress amended the Civil Rights Act in two important ways: (I) The district courts are now authorized to appoint voting referees after finding a pattern of discrimination. The voting referees are to assist the court in receiving and passing upon applications for registration from Negroes in the affected county, if, after court judgment, local officials deny registration to Negroes. ${ }^{\circ}$ (2) The state may be joined as a party defendant in a proceeding involving section I97I(a) rights, or the state alone may be sued if, prior to the institution of the action, the offending state or local officials have resigned and no successors have been appointed..$^{10}$

Title three of the I 600 Act requires that all records and papers relating to registration, the payment of poll taxes, or other acts requisite to voting in federal elections be retained and preserved for a specified period and that they be made available to the Attorney General for inspection and copying. ${ }^{11}$

\section{II}

\section{The Acts in Operation}

The Justice Department is fulfilling its obligations to prevent discrimination and intimidation by pursuing a three-stage program: ( $I$ ) taking corrective action; (2) supervising compliance; (3) conducting in as organized a fashion as possible an expanding program of affirmative action to insure full and free exercise of the franchise by Negro citizens.

Whenever the Department of Justice has reasonable grounds to believe that acts of discrimination or intimidation against Negroes have been committed for the purpose or with the effect of depriving them of the right to vote or of interfering with their exercise of the right to vote, an investigation is conducted. These investigations usually include a thorough analysis of the registration and voting records

connivance by local officials. Their participation with the private individual would supply the necessary element of state action. Cf. Brown v. United States, 204 F.2d 247 (6th Cir. 1953).

It may be that private non-racial denials of the right to vote in local elections are not covered by the act. Fortunately, they rarely occur except in a vote fraud context and then such deprivations are probably covered by federal criminal statutes if local officials are involved. I8 U.S.C. $\$ \$ 37$, 242 (Supp. I96I); cf. United States v. Classic, 313 U.S. 299 (r94I).

Non-coercive, non-racial but arbitrary denials by local officials of the right to vote in federal and local elections can be prosecuted under I8 U.S.C. $\$ \S 24 \mathrm{I}$ and 242 (federal elections) and $\$ 242$ (local elections). See EMERson \& HABER, op. cit. supra, at 158-59.

${ }^{\circ}$ See 601 (a) of the act, now codified as 42 U.S.C. \$ I97I(e) (Supp. I96I) provides that upon a finding by the court that persons have been deprived on account of race of subsection (a) rights, and that such deprivation was or is pursuant to a pattern or practice, any other person of such race within the affected area is, upon his subsequent application, entitled to an order declaring him qualified to vote upon proof that (I) he is qualified under state law to vote, and (2) subsequent to such findings by the court, he has been (a) deprived of the opportunity to register or otherwise to qualify to vote, or (b) found not qualified to vote by any person acting under state law.

${ }^{10} \mathrm{Sec} .60 \mathrm{I}(\mathrm{b})$ of the act amended $\$ 197 \mathrm{I}(\mathrm{c})$ by adding: "Whenever, in a proceeding instituted under this subsection any official of a State or subdivision thereof is alleged to have committed any act or practice constituting a deprivation of any right or privilege secured by subsection (a), the act or practice shall also be deemed that of the State and the State may be joined as a party defendant and, if, prior to the institution of such proceeding, such official has resigned or has been relieved of his office and no successor has assumed such office, the proceeding may be instituted against the State."

${ }^{12}$ Sections 30r-306, 42 U.S.C. $\$ 1974$ et seq. (Supp. I96I). See Kennedy v. Bruce, 298 F.2d 860 (5th Cir. I962). 
of the county involved and extensive interviews with persons in the county by agents of the Federal Bureau of Investigation. If we conclude that discrimination has occurred, the Department makes every effort to correct the illegal practices by bringing them to the attention of state and local officials. If negotiation is unavailing; a suit is filed under section $197 x$.

Between September $195^{8}$ and May 15, I962, twenty-one section 1971(a) suits and six section 1971 (b) suits have been filed under section 197r. By May 15, 1962, five of the section I97I (a) suits had culminated in the issuance of injunctions by the federal courts. In two counties preliminary injunctions favorable to the Government have been issued. Four are awaiting decision on the merits and on one the Government has appealed from the denial of a preliminary injunction. In the section I97I (b) cases, five have been disposed of favorably to the Government by stipulation or consent judgments. The remaining one is awaiting hearing but a preliminary injunction has been issued favorable to the Government pending the hearing. These cases have arisen in five states: Alabama, Georgia, Louisiana, Mississippi, and Tennessee.

As illustrated by the cases discussed below, intimidation is the weapon of those who would suppress completely all Negro interest in voting. The numerous techniques of discrimination are used to frustrate Negroes' attempts to apply to register, to reject the applications of qualified Negroes, to prevent poll tax payments by Negroes, to exclude Negro registrants from primary elections, and, when all else fails, to purge Negro voters from the registration rolls.

\section{A. Illegal Suppression of Negro Voting}

As noted above, four cases have been against defendants who attempted to squelch Negro interest in registration by intimidation, threats, and coercion.

A case which arose in Walthall County, Mississippi, illustrates intimidation by the misuse of local criminal processes. ${ }^{12}$ The defendants are the registrar of voters, the sheriff, city attorney, and the district attorney of Walthall County. The Government's affidavit in support of its motion for a temporary restraining order recites that John Hardy, a Negro who was conducting a registration school in Walthall County, accompanied two local Negro applicants to the registrar's office. They had barely arrived when the registrar ordered Hardy from the office and struck him on the head with a gun as he complied. The sheriff arrested Hardy a few hours later, charged him with disturbing the peace, put him in jail where he was interviewed for several hours by the district attorney with a tape recorder, and required him to post bond before being released and to appear in the justice of the peace court for trial.

The court of appeals has enjoined the state's prosecution of Hardy pending a hearing in the federal district court on our contention that the treatment of Hardy is an illegal intimidation of Walthall County's Negro would-be voters.

\footnotetext{
${ }^{12}$ United States v. Wood, 295 F.2d 772 (5th Cir. 196I), cert. denied, 369 U.S. 850 (1962).
} 
Three cases involving economic coercion arose in Haywood and Fayette counties, Tennessee. ${ }^{13}$ They seek to enjoin more than 150 defendants, including landowners, banks, and business associations, from intimidating and coercing Negro citizens for the purpose of interfering with their right to register to vote in federal elections.

Despite their numerical preponderance in both counties, no Negroes were registered in Haywood in 1959 and very few were on the rolls in Fayette. The Department's complaints charge that when registration by Negroes began in 1959 the defendants undertook to circulate lists of the names of Negroes who were active in the registration movement for the purpose of inducing the white community to engage in a variety of economic reprisals against them, including loss of employment, denial of loans and other credit. The complaint also charged that when this form of intimidation was not successful, the defendants began a series of mass evictions of sharecroppers who had registered to vote. Consent judgments favorable to the Government have just been entered in the Beaty, Barcroft and Atkeison cases. Significantly, about 3,000 and 2,000 Negroes are now registered in Fayette and Haywood counties, respectively.

The fifth case ${ }^{14}$ involved intimidation of Francis Joseph Atlas, a Negro farmer from a Louisiana parish in which no Negroes are registered although they outnumber the white persons. Francis Joseph Atlas, a Negro cotton farmer who had raised twelve children and given college educations to all but the youngest two (they were in high school), tried several times to register to vote. He was told when he took his cotton to be ginned that his cotton wouldn't gin. When he asked why, the ginner replied, "civil rights." Mr. Atlas had been subpoenaed to testify about his efforts to register and when this was known all of the cotton ginners in the community decided that they would not gin any more of Mr. Atlas' cotton.

The soy bean processors refused to process his beans. Merchants from whom Atlas had bought farm supplies refused to trade with him. For example, the one feed store clerk in the store told Atlas that he had orders not to handle sales to Atlas and that he would have to see the manager. Atlas went to the manager and the manager said, "Yes, I gave those orders. I have enough customers without you. I don't need your business. I would appreciate it if you don't come back."

The Department of Justice Complaint asked the court to issue an order requiring the cotton ginners and other merchants in Atlas' community to open the channels of trade to him on the same basis as they were open to other citizens. Under pressure from the court Atlas' cotton was ginned and he is still farming in his community. He is still not registered, but the Government has also brought suit to prevent the local registrars from denying Negroes their franchise and this suit has already been submitted to the district court on the merits.

\footnotetext{
${ }^{13}$ United States v. Beaty, 288 F.2d 653 (6th Cir. 196I); United States v. Barcroft, 288 F.2d 653 (6th Cir. I96r); United States v. Atkeison (W.D. Tenn., No. 4I3I). The Beaty and Barcroft cases were consolidated.

14 United States v. Deal (W.D. La. No. 8132).
} 


\section{B. Discriminatory Disqualification of Negro Applicants}

Where Negroes are unafraid and undeterred by discriminatory rejection of their leaders who attempt to register, they apply in significant numbers. Often there are threshold problems, e.g., registrars secrete themselves in unlikely places in the courthouse and, when ferreted out, they resign their offices which go unfilled for long periods. ${ }^{15}$

- However, most of the rejections of qualified Negroes are effected by the manipulation of the lengthy and intricate registration procedures and standards that are employed in five of the problem states. Many of these "tests" were originally designed to facilitate the arbitrary exclusion of Negro applicants and their present use to that end is widespread. ${ }^{16}$

\section{Identification Device}

Negroes have been prevented from applying for registration by the requirement that they produce one or more registered voters to "vouch" for them, that is, to identify them. Louisiana law authorizes this procedure where the registrar "has good reason to believe that [the applicant] is not the same person" whom he represents himself to be. ${ }^{17}$ The Alabama application form contains a similar requirement. Where few or no Negroes are registered, they are, in effect, dependent upon white voters to vouch for them. Three cases filed by the Department of Justice attack this requirement as applied.

The first case ${ }^{18}$ arose in Bullock County, Alabama, where only five of the $4,45^{\circ}$ Negroes of voting age were registered in Ig60. The county board of registrars had a rule that applicants for registration must be "vouched" for by a registered voter and that a voucher could identify only two applicants in a calendar year. The only Negro applicant during I960 was a minister who was rejected twice. One of the Negro registrants vouched for him on both attempts. Later the voucher accompanied his son, a teacher, to the registration office. The teacher was not permitted to apply because his father had exhausted his "vouches" for I960. The district court invalidated the limitation rule as patently unconstitutional. ${ }^{10}$

The second case $^{20}$ arose in East Carroll Parish, Louisiana. No Negroes have been registered there since Ig22 although they are the adult majority. The suit charges that Negroes have been effectively denied the opportunity to apply by the requirement that they must produce two registered voters to identify them. White

${ }^{26}$ C.R.C. REPORT 75-75 (x959).

${ }^{16}$ C.R.C. REPORT 31-33 (1959). See also Davis v. Schnell, 81 F. Supp. 872 (S.D. Ala. 1949), aff'd, 336 U.S. 933 (I949).

27 "The applicant shall in all cases be able to establish that he is the identical person whom he represents himself to be when applying for registration. If the registrar has good reason to believe that he is not the same person, he may require the applicant to produce two credible registered voters of his precinct to make oath to that effect." LA. REv. STAт. tit. 18, \$37 (1950).

${ }^{18}$ United States v. Alabama (M.D. Ala., No. $1677-\mathrm{N}$ ).

${ }^{19} \mathrm{Ibid}$. (unreported). Other issues and enforcement problems in this case will be dealt with infra. For an earlier chapter in that county's voting history, see Sellers v. Wilson, 123 F. Supp. 917 (M.D. Ala. 1954).

${ }^{20}$ United States v. Manning, 205 F. Supp. I72 (W.D. La. I962). 
persons have had no difficulty with the identification requirement because, among other reasons, they are permitted to be identified by their previous registration. The case was decided favorably to the Government; as of mid-July the procedures of the r 960 statute were being invoked to determine the qualifications of Negro applicants.

The third case ${ }^{21}$ arose in Madison Parish, Louisiana, where no Negro has been registered since Igoo. The facts alleged are essentially those of the East Carroll case. No trial date has been set.

The discriminatory use of Louisiana's identification requirement was held unconstitutional in 1952 when the registrar of voters of Bossier Parish was enjoined from engaging in this practice. ${ }^{22}$ This illustrates one of the recurrent problems faced by the Department of Justice: one injunction against a practice does not necessarily end that practice in other counties. The result is a time-consuming multiplicity of suits.

\section{Devices Involving Literacy and Understanding}

Negroes who overcome the threshold problems and make application to register may be rejected on one or several grounds even though they possess the same qualifications as white persons who are registered in the county. This results from the discretion vested in registrars to administer ostensibly neutral literacy and understanding tests. In some states, including Georgia and Alabama, applicants for registration are required to be able to read and write any paragraph (or article) of the Constitution of the United States (or of the state). ${ }^{23}$ In Alabama applicants are also required to fill out a lengthy application and questionnaire without assistance. ${ }^{24}$

In Louisiana and Mississippi applicants for registration are required to understand (or read) and give a reasonable interpretation of any section of the constitution of the state (or of the United States). ${ }^{25}$ These states also require each applicant to fill out a form without assistance. ${ }^{28}$

(a) The Read and Write Test. The Georgia and Alabama reading and writing requirements have been involved in two cases brought by the Department of Justice under section $197 \mathrm{I}(\mathrm{a})$.

In United States v. Ward (W.D. La., No. 8547).

${ }^{22}$ Byrd v. Brice, ro 4 F. Supp. 442 (W.D. La. 1952), aff'd, 201 F.2d 664 (5th Cir. I953).

"Alabama: "The following persons, and no others . . . shall be qualified to register as electors ... : those who can read and write any article of the Constitution of the United States in the English language which may be submitted to them by the board of registrars ...." (ALA. Consr. \$ I8I, Amend. XCI). Georgia: "Every citizen of the State shall be entitled to register as an elector . . . who . . . comes within cither of the classes provided for in the two following subdivisions: ( 1 ) all persons who are of good character and understand the duties and obligations of citizenship under a republican form of government; or (2) all persons who can correctly read in the English language any paragraph of the Constitution of the United States or of the State and correctly write the same in the English language when read to them by any one of the registrars ...." GA. Const. $\$ 2-704$ (1945).

"Als. CoNst. $\$ 18 x$, Amend. XCI. Neither Alabama nor any of its Boards of Registrars has promulgated answers to the questions, many of which are difficult and ambiguous. C.R.C. REPORT 73 (I959).

${ }^{25} \mathrm{LA}$. ConsT. art. VIII, $\S$ (D) (1922), as amended; Miss. CoNST. $\$ 244$, as amended.

${ }^{20}$ LA. CoNst. art. VIII, $\$$ I(C) (1922), as amended; Miss. Const. $\$ 244$, as amended. 
. One case ${ }^{27}$ arose in Terrell County, Georgia, where only fifty-three of 4,057 Negroes over $x 8$ were registered in 1958 . Negro school teachers had been denied registration on account of their failure to pass the oral reading test. One of the teachers mispronounced the word "equity." A Negro applicant with one year of college was rejected on the ground that he could not write legibly. In fact, by dictating unreasonably fast, the registrar made it impossible for the applicant to transcribe the passage accurately. The court found that Negroes were required to read and write more lengthy and difficult constitutional provisions, that the procedures resulted in easier tests for white applicants, and that a higher literacy level was required of Negroes. ${ }^{28}$

The Alabama case ${ }^{29}$ arose in Macon County where Negro applicants, including many with college degrees, had been denied registration on the ground that they had made "errors" in filling out their applications. White applicants, including at least one illiterate and others with little or no education, were assisted in filling out their applications and were registered.

Negro applicants were repeatedly required to copy lengthy portions of the Constitution, ostensibly to demonstrate their literacy. For example, Mrs. Marie Williams, who had had three years of college and who applied unsuccessfully five times, was required on each try to copy article two of the United States Constitution (about I,000 words). She wrote a total of twenty pages. Thus was the literacy test used to discourage and delay Negro registration.

(b) The Application Form as a Test. In counties in Alabama, Mississippi, and Louisiana the application forms themselves have been used as a test. These forms appear to be intended to secure routine, superficial information about the applicant and they are unobjectionable when used in this way. But, again and again, well educated Negroes, who set forth all the substantive data called for, have been denied registration because they made trivial errors on the form. Because the states have not issued prescribed answers, even to the registrars, eminently qualified Negroes are compelled to play a humiliating, futile form game with registrars who set their own standards and who often refuse to apprise unsuccessful applicants as to where they erred.

Conversely, white applicants usually get all the help they need, from each other and from the registrars to fill out the form. Moreover, white applicants whose forms contain errors for which Negroes are rejected are almost invariably registered if the basic information requested by the form appears on it in some comprehensible way.

Several cases illustrate these practices. In one Alabama action ${ }^{30}$ the Government showed that, between January I, I956 and June I6, I96I, a board of registrars accepted 96.6 per cent of the white applicants while rejecting 75.4 per cent of the applications

\footnotetext{
${ }^{27}$ United States v. Raines, r89 F. Supp. 121 (M.D. Ga. 1960).

28 Ibid.

${ }^{20}$ United States v. Alabama, I92 F. Supp. 677 (M.D. Ala. 196I).

${ }^{30}$ United States v. Penton (M.D. Ala., No. $174 \mathrm{r}-\mathrm{N}$ ).
} 
by Negroes. Seven hundred and ten of the "unqualified" Negroes had twelve or more years of formal education and among them they had filed over r,200 applications. These Negroes' applications were rejected as improperly executed. It developed that, as applied to white persons, the forms were questionnaires, not tests.

Similarly, documents and testimony in a Mississippi case ${ }^{31}$ disclose that white registrants' applications bear " $x$ " marks at an oath line which Negroes, whose applications are unmarked, were rejected for their failure to sign.

Finally, several thousand Negro voters were challenged and removed from the rolls in Louisiana on the ground that they had made errors in filling out their original application cards. White registrants who had made similar or worse errors were not even challenged. The Department of Justice has attacked this practice in four cases under section $1971(a)^{32}$ and the two cases decided have resulted in the restoration to the voting rolls of more than $\mathrm{I}, 800$ Negroes. ${ }^{33}$

(c) The Interpretation Test. The Louisiana interpretation test has been challenged per se in United States v. Louisiana. ${ }^{34}$ The requirement that applicants for registration must be able to understand and give a reasonable interpretation of any section of the Constitution is attacked on the ground that the history and setting in which this test was adopted and has been enforced, and the uncontrolled discretion which is vested in registrars who administer the test, render it unconstitutional under section $197 \mathrm{I}$ and under the fourteenth and fifteenth amendments.

The discriminatory administration of the test is challenged in four other suits which have previously been filed by the Department under section $197^{\mathrm{x}}{ }^{35}$ Only one of these cases has been tried and decided. ${ }^{36}$ There, Negro school teachers, one of whom had a Master's degree from Stanford University, were denied registration on the ground that they did not interpret a provision of the Constitution to the satisfaction of the registrar. The court found that less stringent standards were applied to white applicants, who were invariably registered, than to Negro applicants, none of whom had been registered. On the other hand once the registrar adopted the formality of giving the constitutional interpretation tests to whites, sections such as "there shall be no imprisonment for debt" were used or if the section was harder the white applicant was given an opportunity to copy an answer.

The Government's proof on a motion for a preliminary injunction in a Mississippi case $^{37}$ shows that all Negro applicants have been subjected to the interpretation test

${ }^{31}$ United States v. Lynd (S.D. Miss., No. I646).

${ }^{32}$ United States v. McElveen, I80 F. Supp. 10 (E.D. La. I959), affd sub nom. United States v. Thomas, 362 U.S. 58 (1960); United States v. Association of Citizens Councils of Louisiana, 196 F. Supp. go8 (W.D. La. I96I); United States v. Manning stupra note 20. United States v. Ward (W.D. La., No. 8547).

${ }^{3}$ United States v. McElveen, supra note 32; United States v. Association of Citizens Councils of Louisiana, supra note 32 .

${ }^{34}$ E.D. La., No. 2548 .

${ }^{35}$ United States v. Lucky (W.D. La. No. 8366); United States v. Fox (E.D. La., No. I1625); United States v. Wilder (W.D. La., No. 8695); United States v. Association of Citizens Councils of Louisiana, supra note 32.

${ }^{30}$ United States v. Association of Citizens Councils of Louisiana, supra note 32.

a7 United States v. Lynd, supra note $3 \mathrm{~T}$. 
but that none of the white persons took it before January 196r. Moreover, the Negroes are invariably confronted with lengthy, highly legalistic provisions and none has been registered since the mid-fifties.

\section{Impeding Poll Tax Payments by Negroes}

Five states now require the payment of poll taxes as a prerequisite to voting, although not to registration..$^{38}$ By now the tax itself is a negligible, bi-racial deterrent to voting. However, local officials occasionally manipulate the requirement so as to disfranchise Negroes.

In one Mississippi county white voters pay their poll taxes to "collecting deputies" in either of the county sheriff's widely separated offices. Negroes who proffer their payments to the deputies are invariably told to see the sheriff, who is rarely in either office and never in both.

The section $\operatorname{Ig7r}^{\mathrm{I}}$ (a) case, which seeks to equalize the payment procedures, is presently on appeal from the district court's denial of the Government's motion for a preliminary injunction. ${ }^{39}$

\section{A White Primary}

It is generally assumed that white primaries are extinct. In 1959, however, as Negroes began to register in significant numbers in rural Fayette County, Tennessee, local Democratic leaders hit upon a plan to insure continued white control of county offices. For the biennial local primary, election notices were placed in each ballot box to the effect that voter participation was confined to white Democrats. The election officials followed the notices and our section $\operatorname{rg7r}$ (a) suit followed the election. ${ }^{40}$

A consent judgment barring discrimination in any process used to select local candidates was entered prior to the rg6r primary in which Negroes voted freely.

\section{III}

\section{Enforcement: Techniques and Problems}

The preceding section considered the kinds of discrimination and intimidation that Negroes have encountered in their efforts to vote and the remedial actions undertaken by the Justice Department.

This section outlines the practical problems that must be dealt with in order to secure the issuance of, and compliance with, an effective court decree.

\section{A. The Case Before Judgment}

Cases begin in several ways. Negro victims of obvious discrimination, e.g., those who are unable to find elusive registrars and those who are not permitted to make application, often complain formally to the Department. ${ }^{41}$ However, Negroes,

${ }^{38}$ Alabama, Arkansas, Mississippi, Texas, and Virginia.

${ }^{30}$ United States v. Dogan (N.D. Miss. I962).

10 United States v. Fayette County Democratic Executive Committee (W.D. Tenn., No. 3835, 1960).

12 The same is true of intimidation cases. Our threshold problems are greater here, however, because 
especially in rural areas, are frequently unaware of the discrimination that is occurring. Those who fill out lengthy forms and attempt to explain intricate constitutional provisions are not surprised to be told that they have erred and are not qualified under the state's stringent standards. Because communication between the white and Negro communities is minimal on these matters, the Negroes do not know that the tests are applied only to them. Thus, the Negroes often concentrate on improving their performance level by studying registration forms and taking practice registration tests without realizing that they may already be qualified under the standards by which white persons are registered. In communities where the complete segregation of the races is a long-standing tradition, voting by white persons is regarded as a routine corollary of citizenship to which they are presumptively entitled; Negroes, however, bear the burden of proving that they are "qualified." As a result, we have not received complaints from many counties in which seventy to eighty per cent of the white adults are registered but only a handful of Negroes, although many have applied.

We have sought to bridge this gap by inquiring about low Negro registration in statistically suspicious counties. If our inquiry discloses that applicants are being rejected, we may then seek to inspect and copy the registration records, application forms, and the like. These may reveal evidence of discrimination, such as that white persons' forms have been filled out by the registrar, or that Negroes' applications are graded more strictly. In this way we also secure the names of registrants and rejectees of both races in order to interview them for a comparative analysis of the processing of white and Negro applicants.

In those instances where the records will not be too helpful ${ }^{42}$ or to secure them will require time-consuming litigation, we initiate the "records demand" process while proceeding along other lines. That is, we do not wait for documentary evidence of discrimination to proceed in a county if most white adults are registered and qualified Negroes are being turned down. These two facts alone establish a case of discrimination. ${ }^{43}$ Only the details of the techniques of discrimination are lacking, and they can be supplied through discovery proceedings and further extensive investigation.

The responses to our complaints vary, of course, with the caliber of our legal opposition. At their extremes the reactions are newspaper diatribes and innumerable ingenious, dilatory motions. ${ }^{44}$

Negroes who do not apply to register on account of fear do not, for the same reason, complain to the Department.

${ }^{12}$ Where applicants are required to read aloud a portion of a constitution (South Carolina), or to interpret orally a section of a constitution (Louisiana), there will not be any written record of those parts of the qualification tests.

${ }^{13}$ Cf. Byrd v. Brice, supra note 22.

"The success of such motions varies from (judicial) district to district. By responding promptly to all motions we seek to minimize the law's delays and to avoid being, in effect, required to acquiesce in opposing counsels' requests for extensions of time. Nevertheless, dilatory tactics have had some success because of crowded docket and, in some cases, judges that are hostile to civil rights cases. Although the average length of time between complaint and trial in our cases is just under six months, we have 
A racial registration trial is usually highlighted by the absurd contrast between the testimony of Negro teachers about their failures to qualify and the efforts of white semi-literate registrants to explain how they got on the voter rolls. For several reasons, however, the less spectacular registration records are the heart of a case. In all counties, however small, the combined totals of white persons accepted and Negroes rejected amount to too many individual instances of discrimination to be presented to the court by live testimony. Moreover, each person's experience is a tiny chip in the huge mosaic that is the history of registration in the county. The records are usually the repository of those fragments and, by thorough, careful analysis before trial, they can be made to tell the county's voting story. For instance, Alabama requires, among other things, that its applicants fill out correctly an application and a 2I-question form of four pages. To analyze the form of each of the thousands of applicants accepted and rejected is a formidable but fruitful task. Thus, in the Montgomery County, Alabama, case ${ }^{45}$ the Government filed a largely factual brief of 293 pages and eight attachment volumes of documents depicting graphically, statistically, and otherwise every item of the many forms of discrimination that characterized registration there in recent years.

The records disclose not only past discrimination; they are the best evidence of the county's actual registration standards. As a suit looms, registrars often become impossibly exacting with all applicants without distinction of race. Frequently new registrars take over by reason of resignations or simple expiration of terms of office, and even with the best of motives, the new registrars cannot know without investigation (which is in fact best supplied by the evidence brought in litigation) as to past practices. Such events freeze registration and clearly create inevitable discrimination in counties with, say, ninety per cent of the adult whites, but only ten per cent of the adult Negroes presently on the rolls as a result of past discrimination. It is our view that the de facto registration standards of the recent past must continue in effect; alternatively, all voters must register anew if the requirements are to be changed. ${ }^{46}$

An exhaustive analysis of the records enables the court to articulate precisely in its decree the standards by which applications are to be judged by the registrars or a voting referee.

\section{B. Enforcement of the Decree}

As a trial ends we present to the court a proposed decree, as well as findings of fact and conclusions of law, in which we specify precisely the discriminatory procedures to be enjoined. With myriad opportunities for discrimination, a general

encountered some serious delays. United States v. Raines, 189 F. Supp. I21 (M.D. Ga. 1960), was tried $2 I$ months after the complaint was filed; United States v. Majors (S.D. Ala., No. 2584) was tried in May I962, 13 months after the filing of the complaint; United States v. Lucky (W.D. La., No. 8366) was begun in July $196 \mathrm{r}$, and no trial date has been set. No trial dates have been set in three Mississippi cases that were filed in $196 \mathrm{I}$.

15 United States v. Penton, stupra note 30.

${ }^{\circ} \mathrm{Clearly}$, a tightening of standards discriminates against those who are unregistered at the time of the change. 
injunction not to discriminate is ineffective against registrars who are unwilling or unable to be fair. Moreover, good faith registrars require clear guidelines to administer fairly the highly subjective registration tests. ${ }^{47}$

It is too early to make more than a tentative judgment on the workability and curative effects of the courts' decrees. ${ }^{48}$ Unquestionably, however, a court's power to hold recalcitrant defendants in contempt induces some measure of compliance with its orders. Moreover, the knowledge that a federal voting referee may be appointed in the event of non-compliance spurs circumspection among local officials to whom "outside interference" is as much anathema as Negro voting. Finally, the courts" decrees usually give us continual or periodic access to the records as well as requiring the defendants to document their doings and to file complete reports with the courts at specified intervals. Of course, judicial and departmental ubiquity are impossible and undesirable.

We are trying to secure compliance with the law through decrees that are effective but not onerous, enforceable but not harassing.

\section{A Case's Repercussions}

While it is still too early to write confidently of all the effects of a voting case, clearly the first case in a judicial district is educational for all concerned. The courts, we, and defense counsel know better the materials that will be subject matter of any subsequent controversies. We know each other, too. More important, the Negro communities in neighboring counties learn more of the role of the Department of Justice and of their own opportunities. Conversely, nearby registrars may become fairer in their testing of Negro applicants.

Finally, there is a new awareness that the United States Department of Justice is determined to make discrimination against Negro voters unknown in this land. This awareness, and our activities, expand in an organized fashion from county to county within a judicial district so that the Negro citizens of one county, as well as moderate and responsible white citizens, are able to witness the experience of their neighbors in giving effect to the democratic processes required by the Constitution. Our experience is that this mushrooming growth of recognition of the civil right to vote makes the inevitability of the process known and accepted and the transition easier.

"The present Administration's proposed "literacy" bill (H.R. 10034) S. 2750, 87th Cong., 2d Sess. (I962) would go far toward eliminating the discrimination that almost inevitably occurs when a southern white man applies a subjective standard to a Negro. The bill equates intelligence sufficient for voting with a sixth grade education by providing that accredited sixth-graders shall not be required to pass tests to qualify to vote in federal elections.

\$8 There has been no significant increase in Negro registration in Terrell County, Georgia, since the decree in United States v. Raines, supra note 27. However, about 1,700 Negroes registered in Macon County, Alabama, in the year after the court order was issued. 